\title{
PERAN MINAT PEMBELIAN KONSUMEN SEBAGAI MEDIASI KUALITAS PRODUK TERHADAP KEPUTUSAN PEMBELIAN PADA PERUSAHAAN KUE
}

\author{
Muhammad Ari Adriansyah; Rudy Aryanto; Harly Toindo; Shirley Agusthina
}

Management Department, School of Business Management, BINUS University

Jln. K. H. Syahdan No. 9, Palmerah, Jakarta Barat 11480

raryanto@binus.edu; harly@binus.edu; sagusthina@binus.edu

\begin{abstract}
Cookie companies are demanded to improve their product quality, product quality is one of the important things. Because with a good product quality, it will deliver purchase intention; with the intention earned by customer, it will also deliver the purchase decision process. The purpose of this research is to analyse the effect of product quality towards purchase intention and its impact on the purchase decision process. The method used in this research is descriptive-associative, with Path Analysis. Questionnaires were distributed to $J \& C$ Cookies' consumers. The findings of this research show that the product quality gives a big influence to customer's purchase intention and gives a big and positive impact on purchase decision process of J\&C Cookies' customers.
\end{abstract}

Keywords: product quality, purchase intention,purchase decision

\begin{abstract}
ABSTRAK
Perusahaan kue kering dituntut untuk meningkatkan kualitas produk mereka. Kualitas produk merupakan salah satu hal penting. Dengan kualitas produk yang baik, hal itu akan mengantarkan niat pembelian; dengan niat yang diterima oleh pelanggan, hal itu akan menyampaikan proses keputusan pembelian. Tujuan dari penelitian ini adalah untuk menganalisis pengaruh kualitas produk terhadap niat membeli dan dampaknya terhadap proses keputusan pembelian. Metode yang digunakan dalam penelitian ini adalah deskriptif-asosiatif, dengan Path Analysis. Kuesioner dibagikan kepada konsumen J\&C Cookies. Temuan penelitian ini menunjukkan bahwa kualitas produk memberikan pengaruh yang besar terhadap niat beli pelanggan dan memberikan dampak yang besar dan positif terhadap proses keputusan pembelian dari pelanggan J \& C Cookies.
\end{abstract}

Kata kunci: kualitas produk, niat pembelian, keputusan pembelian 


\section{PENDAHULUAN}

Seiring dengan kegemaran masyarakat Indonesia dalam mengonsumsi makanan ringan, kue kering merupakan alternatif konsumen dalam memenuhi kebutuhan masyarakat. Kue kering merupakan makanan ringan yang dapat dinikmati untuk konsumsi pribadi ataupun bingkisan pada relasi dan keluarga untuk momen yang spesial seperti hari raya Lebaran, Natal, dan lain-lain. Kue kering tersedia dalam berbagai jenis tampilan dan varian rasa agar konsumen dapat merasakan pengalaman yang berbeda dalam mengonsumsi kue kering. Perkembangan saat ini menjadikan persaingan dalam bisnis kue kering sangat kompetitif. Perkembangan ini dapat dilihat dengan banyaknya orang mengirim parcel sebagai bentuk ucapan terima kasih atau ucapan selamat kepada seseorang atau keluarga, yang isi parcel tersebut adalah kue kering. Khususnya pada hari raya Lebaran dengan permintaan masyarakat terhadap kue kering meningkat drastis hingga meningkat $50 \%$ dibanding hari biasa pada periode bulan puasa dan jelang Ramadhan, seperti dikutip oleh seorang pemilik usaha kue kering. Hal ini mendorong para pengusaha berlomba-lomba untuk memasuki bisnis kue kering dengan menawarkan berbagai macam kualitas dan aneka rasa dengan harga yang bersaing. Banyaknya pengusaha yang memasuki bisnis kue kering ini menjadikan konsumen bingung untuk memilih kue kering yang harus dibeli oleh konsumen. Pengusaha kue kering berlomba-lomba menarik perhatian konsumen dengan menerapkan strategi-strategi agar kue keringnya dapat laku dibeli oleh konsumen. Salah satu strategi yang diterapkan oleh pengusaha kue kering adalah meningkatkan kualitas produk kue kering tersebut. Kue kering yang menjadi pilihan konsumen adalah kue kering yang mampu menawarkan kelezatan, cita rasa yang sesuai dengan selera konsumen, dan menggunakan bahan-bahan berkualitas. Hal ini dilakukan agar seluruh produk yang ditawarkan akan mendapat tempat baik di mata masyarakat selaku konsumen atau calon konsumen, karena dalam memilih produk didasari minat membeli yang nantinya memengaruhi jenis, cita rasa produk yang dibelinya. Oleh karena itu, para pengusaha/perusahaan kue kering dituntut untuk terus melakukan perbaikan terutama pada kualitas produknya.

Perusahaan kue kering yang cukup sukses di Indonesia salah satunya adalah J\&C Cookies. Berdiri pada 1996, J\&C Cookies adalah sebuah merek kue kering roombutter berstandar internasional. Kue J\&C diproses dan diolah secara higienis menggunakan bahan baku berkualitas tinggi sehingga menghasilkan kue kering tanpa bahan pengawet dengan cita rasa yang khas. Setelah 14 tahun berdiri, J\&C Cookies yang pertama kali didirikan di Bandung telah mengembangkan usahanya hingga ke banyak pelosok daerah di Indonesia seperti Jakarta, Depok, Bekasi, Surabaya, Batam, Bengkulu, Bali, Semarang bahkan hingga ke mancanegara. J\&C Cookies diolah secara higienis melalui tangan-tangan terampil, dikemas secara menarik, serta didukung dengan teknologi yang modern. Dalam memenuhi standar kesehatan dan keamanan pangan, selain mendapatkan izin dari Dinas Kesehatan, sertifikat halal MUI, saat ini J\&C Cookies juga disertifikasi standar internasional HACCP. HAACP (Hazard Analysis Critical Control Point) adalah suatu sistem kontrol dalam upaya pencegahan terjadinya masalah yang didasarkan atas identifikasi titik-titik kritis di dalam tahap penanganan dan proses produksi. HACCP merupakan salah satu bentuk manajemen risiko yang dikembangkan untuk menjamin keamanan pangan dengan pendekatan pencegahan (preventive) yang dianggap dapat memberikan jaminan dalam menghasilkan makanan yang aman bagi konsumen. J\&C Cookies memiliki produk dengan keunggulan tinggi, karena menggunakan bahan-bahan berkualitas. J\&C Cookies menyediakan 53 macam kue kering dengan kelezatan rasa yang khas. Selain kue kering, J\&C juga melengkapi produknya dengan berbagai macam pilihan kemasan parcel yang cantik dan elegan, sangat cocok untuk bingkisan kepada relasi dan keluarga saat momen yang spesial. Oleh karena itu, dilakukan penelitian ini. 


\section{Studi Pustaka}

Penelitian terdahulu yang dilakukan oleh Budiyono, Bernard NM (2004) menyatakan bahwa kualitas dapat dinyatakan sebagai sebagai harapan dan persepsi para konsumen yang sama baiknya dengan kinerja yang sesungguhnya. Kualitas produk harus sesuai dengan yang dijanjikan oleh semua kegiatan dalam bauran pemasaran. Bagi calon pemakai kualitas produk ini memang harus dikomunikasikan dengan baik karena dapat membangun minat pelanggan untuk membeli produk yang dimaksud. Hasil penelitian menunjukkan bahwa kualitas produk merupakan antecedent yang berpengaruh terhadap minat beli. Berdasarkan hasil telaah pustakan dan bukti empiris dari penelitian terdahulu, maka hipotesis yang diajukan adalah makin tinggi kualitas suatu produk, akan makin tinggi pula minat beli produk tersebut. Penelitian terdahulu yang dilakukan oleh CP. Saputra (2009) menunjukkan variabel kualitas produk atas harga memiliki pengaruh yang signifikan terhadap keputusan pembelian, terdapat pengaruh yang signikan antara kualitas produk dan harga secara bersama-sama (simultan) terhadap keputusan pembelian produk Telkom FLEXI. Penelitian terdahulu yang dilakukan oleh Herche dalam Yoestini dan Eva (2007) menunjukkan kaitan antara minat beli dan keputusan pembelian. Minat beli konsumen yang tinggi akan mendorong konsumen membeli suatu produk. Sebaliknya, minat beli konsumen yang rendah akan mencegah konsumen untuk membeli produk.

Menurut Kotler and Armstrong (2004) arti dari kualitas produk adalah "the ability of a product to perform its functions, it includes the product's overall durability, reliability, precision, ease of operation and repair, and other valued attributes". Yang artinya, kemampuan sebuah produk dalam memperagakan fungsinya hal itu termasuk keseluruhan durabilitas, reliabilitas, ketepatan, kemudahan pengoperasian, dan reparasi produk juga atribut produk lainnya. Pengertian minat beli menurut Howard yang dikutip dalam Durianto dan Liana (2004) adalah minat beli merupakan sesuatu yang berhubungan dengan rencana konsumen untuk membeli produk tertentu serta banyak unit produk yang dibutuhkan pada periode tertentu. Dapat dikatakan bahwa minat beli merupakan pernyataan mental dari dari konsumen yang merefleksikan rencana pembelian sejumlah produk dengan merek tertentu. Hal ini sangat diperlukan oleh para pemasar untuk mengetahui minat beli konsumen terhadap suatu produk, baik para pemasar maupun ahli ekonomi menggunakan variabel minat untuk memprediksi perilaku konsumen pada masa yang akan datang. Menurut Shiffman dan Kanuk (2004): "proses pengambilan keputusan adalah seleksi terhadap dua pilihan atau lebih. Dengan perkataan lain, pilihan alternatif harus tersedia bagi seseorang ketika mengambil keputusan".

\section{METODE PENELITIAN}

Berdasarkan tingkat eksplanasi, penelitian ini menggunakan jenis penelitian asosiatif. Menurut Sugiyono (2004) penelitian asosiatif merupakan penelitian yang bertujuan untuk mengetahui hubungan antara dua variabel atau lebih. Dengan penelitian asosiatif ini dapat diketahui hubungan antara variabel dan tingkat ketergantungan antara variabel independent terhadap variabel dependent. Dengan penelitian ini, maka akan dapat dibangun suatu teori yang dapat berfungsi untuk menjelaskan, meramalkan, dan mengontrol suatu gejala.

Dalam pelaksanaannya metode penelitian yang dilakukan adalah survei. Kerlinger yang dikutip oleh Sugiyono (2007) mengemukakan bahwa, penelitian survei adalah penelitian yang dilakukan pada populasi besar maupun kecil, tetapi data yang dipelajari adalah data dari sampel yang diambil dari populasi tersebut, sehingga ditemukan kejadian-kejadian relatif, distribusi, dan hubunganhubungan antarvariabel sosiologis maupun psikologis. Metode survei dalam penelitian ini melalui penyebaran kuesioner yang dilakukan kepada pelanggan. Unit analisis berupa individu, yaitu para pelanggan dari J\&C Cookies. Time Horizon yang digunakan adalah cross sectional, yaitu sekumpulan data untuk meneliti fenomena tertentu dalam satu kurun waktu saja (Umar, 2005). 
Jenis data dalam penelitian dapat dikelompokkan menjadi hal utama yaitu data kualitatif dan kuantitatif. Data kualitatif adalah data yang berbentuk kata, kalimat, skema, dan gambar (Sugiyono, 2007). Data kualitatif yang diangkakan (scoring) misalnya terdapat dalam skala pengukuran. Suatu pertanyaan/pernyataan yang memerlukan alternatif jawaban, sangat setuju, setuju, netral, tidak setuju, sangat tidak setuju yang masing-masing diberi angka $5,4,3,2$, dan 1 . Dalam penelitian ini peneliti menggunakan data kualitatif yang diubah menjadi kuantitatif karena dibutuhkan skala pengukuran dalam pengolahan data. Menurut Sugiyono (2007) populasi adalah wilayah generalisasi yang terdiri atas: objek/subjek yang mempunyai kualitas dan karakteristik tertentu yang diterapkan oleh peneliti untuk dipelajari dan kemudian ditarik kesimpulan. Populasi dari penelitian ini adalah pelanggan dari J\&C Cookies. Sampel adalah bagian dari jumlah dan karakteristik yang dimiliki oleh populasi tersebut. Sampel yang diambil dari populasi harus representatif (mewakili). Dalam mengambil sampel, digunakan teknik sampling. untuk menentukan sampel yang akan digunakan dalam penelitian, terdapat berbagai teknik sampling yang digunakan. Menurut Sugiyono (2007) teknik sampling pada dasarnya dapat dikelompokkan menjadi dua, yaitu probability sampling dan nonprobability sampling, dengan peluang setiap sampel utuk terpilih sebagai contoh tidak dapat diketahui dengan pasti. Teknik pengambilan sampel yang digunakan yaitu probability sampling dengan fokus pada simple random sampling yang merupakan cara pengambilan sampel dari anggota populasi secara acak tanpa memerhatikan strata (kelompok). Dalam penelitian ini, sampelnya adalah siapa saja pelanggan J\&C Cookies.

Metode analisis yang digunakan adalah Analisis Jalur (Path Analysis). Analisis ini akan digunakan dalam menguji besarnya pengaruh yang ditujukan oleh koefisien jalur pada setiap diagram jalur dari hubungan antarvariabel $\mathrm{X}$ berpengaruh terhadap variabel $\mathrm{Z}$ secara langsung dan secara tidak langsung memengaruhi variabel $\mathrm{Z}$ melalui variabel $\mathrm{Y}$. Penyebaran kuesioner dilakukan secara tertutup dan analisis digunakan teknik korelasi yang merupakan dasar dari perhitungan koefisien jalur. Proses pengolahan data menggunakan komputer dengan program SPSS windows 17.0.

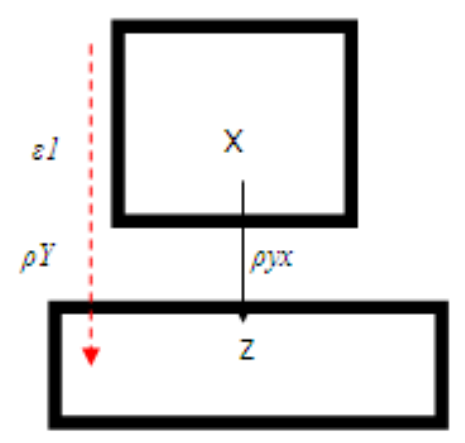

Gambar 1 Substruktur 1 Analisis Jalur

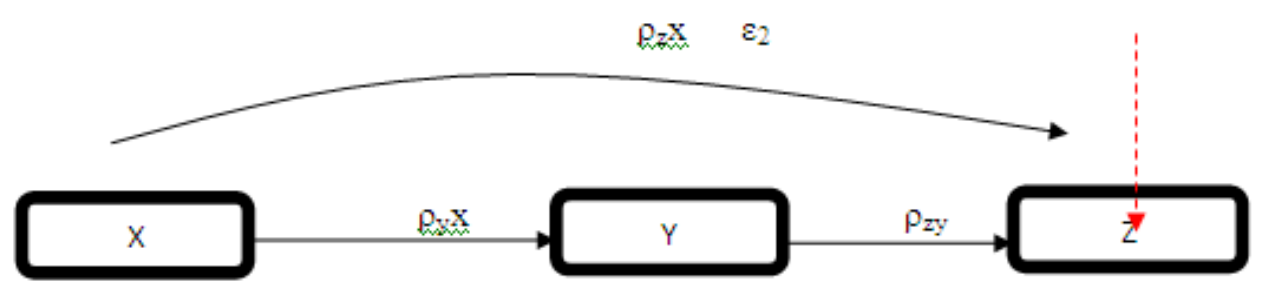

Gambar 2 Substruktur 2 Analisis Jalur 


\section{HASIL DAN PEMBAHASAN}

\section{Analisis Pengaruh Kualitas Produk terhadap Minat Pembelian}

Selanjutnya, untuk melihat hubungan X terhadap Y dibantu dengan menggunakan program SPSS yang menghasilkan output yang menggambarkan hubungan tersebut. Adapun hasil output tersebut adalah sebagai berikut.

Tabel 1 Descriptive Statistics

\begin{tabular}{llrr}
\hline & Mean & Std. Deviation & N \\
\hline Minat Pembelian & 3.396837 & .5495736 & 100 \\
Kualitas Produk & 3.473963 & .5886817 & 100 \\
\hline
\end{tabular}

Untuk mengintepretasikan statistik deskriptif data, akan dibuat terlebih dahulu suatu kriteria mengenai arti nilai masing-masing variabel yang diteliti, yaitu variabel Kualitas Produk (X), Minat Pembelian $(\mathrm{Y})$, dan Keputusan Pembelian (Z). Untuk menentukan kriteria tersebut, digunakan rumus Sturges untuk menghitung jumlah kelas (k) dan lebar kelas (l), dengan jumlah kelas (k) telah ditentukan terlebih dahulu yaitu sebanyak 5 kelas, yaitu kelas pertama "sangat buruk", kelas kedua "buruk", kelas ketiga "cukup", kelas keempat "baik", kelas kelima "sangat baik". Adapun rumus Sturges untuk lebar kelas (1), yaitu:

$$
1=\left(\mathrm{X}_{\max }-\mathrm{X}_{\min }\right) / \mathrm{k}
$$

Untuk variabel $\mathrm{X}$, $\mathrm{Y}$, dan $\mathrm{Z}$ menggunakan nilai baru pada skala interval (bukan skala ordinal). Sehingga kriteria penilaian jawaban untuk variabel X, Y, dan Z adalah sebagai berikut dalam Tabel 2 .

Tabel 2 Interpretasi Variabel X, Y, dan Z

\begin{tabular}{cc}
\hline Interval Variabel X & Kriteria \\
\hline $1,00-1,76$ & Sangat Buruk \\
$1,77-2,53$ & Buruk \\
$2,54-3,30$ & Cukup \\
$3,31-4,07$ & Baik \\
$4,08-4,84$ & Sangat Baik \\
\hline Interval Variabel Y & Kriteria \\
\hline $1,00-1,78$ & Sangat Buruk \\
$1,79-2,57$ & Buruk \\
$2,58-3,36$ & Cukup \\
$3,37-4,15$ & Baik \\
$4,16-4,94$ & Sangat Baik \\
\hline Interval Variabel Z & Kriteria \\
\hline $1,00-1,73$ & Sangat Buruk \\
$1,74-2,47$ & Buruk \\
$2,48-3,21$ & Cukup \\
$3,22-3,95$ & Baik \\
$3,96-4,69$ & Sangat Baik \\
\hline
\end{tabular}

Pada Tabel 1, terlihat mean (rata-rata) dari variabel Kualitas Produk $(\mathrm{X})=3,473963$ yang dengan mengacu pada tabel 2, maka dapat dikatakan tingkat Kualitas Produk J\&C Cookies adalah baik. Sedangkan tingkat minat pembelian konsumen J\&C Cookies termasuk kategori baik, dengan mean 
dari variabel Minat Pembelian $(\mathrm{Y})=3,396837$. Selain itu, dapat dilihat Standard Deviation untuk variabel Kualitas Produk (X) dan Minat Pembelian (Y) cenderung kecil, sehingga dapat diketahui bahwa variansi jawaban responden cenderung seragam.

\section{Pengujian Secara Simultan antara Variabel Bebas X dengan Variabel Terikat $Y$}

Tabel 3 Model Summary Substruktur 1

\begin{tabular}{|c|c|c|c|c|}
\hline \multicolumn{5}{|c|}{ Model Summary $^{\mathbf{b}}$} \\
\hline Model & $\mathbf{R}$ & R Square & $\begin{array}{l}\text { Adjusted R } \\
\text { Square }\end{array}$ & $\begin{array}{l}\text { Std. Error of } \\
\text { the Estimate }\end{array}$ \\
\hline 1 & $.577^{\mathrm{a}}$ & .332 & .326 & .4513361 \\
\hline
\end{tabular}

Besarnya pengaruh variabel $\mathrm{X}$ secara simultan terhadap variabel $\mathrm{Y}$ dapat diketahui dengan melihat nilai $\mathrm{R}$ square pada Tabel 3, dengan nilai $\mathrm{R}^{2}=0,332=33,2 \%$. Jadi, nilai dari variabel $\mathrm{Y}$ dipengaruhi oleh variabel $\mathrm{X}$ sebesar $33,2 \%$, sedangkan sisanya sebesar $66,8 \%$ dipengaruhi oleh variabel lain di luar penelitian ini. Sementara itu, besarnya koefisien jalur bagi variabel lain diluar penelitian yang memengaruhi nilai variabel $\mathrm{Y}(\rho \mathrm{Y})=\sqrt{1-R^{2}}=\sqrt{1-0,332}=0,8173$. Masih mengacu pada Tabel 3, nilai $\mathrm{R}$ (koefisien korelasi) diketahui sebesar 0,577. Hal ini berarti hubungan antara variabel bebas $\mathrm{X}$ secara bersama-sama dengan variabel terikat $\mathrm{Y}$ bersifat kuat (karena nilai $\mathrm{R}$ lebih besar dari 0,5) dan searah (karena nilai R positif).

\section{Pengujian Secara Individual antara X terhadap $Y$}

Tabel 4 Coefficients Substruktur 1

\begin{tabular}{|c|c|c|c|c|c|c|}
\hline \multicolumn{7}{|c|}{ Coefficients $^{\mathrm{a}}$} \\
\hline \multirow[b]{2}{*}{ Model } & & \multicolumn{2}{|c|}{$\begin{array}{l}\text { Unstandardized } \\
\text { Coefficients }\end{array}$} & \multirow{2}{*}{$\begin{array}{c}\text { Standardized } \\
\text { Coefficients } \\
\text { Beta }\end{array}$} & \multirow[b]{2}{*}{$\mathbf{T}$} & \multirow[b]{2}{*}{ Sig. } \\
\hline & & B & Std. Error & & & \\
\hline \multirow[t]{2}{*}{1} & (Constant) & 1.527 & .271 & & 5.625 & .000 \\
\hline & KualitasProduk & .538 & .077 & .577 & 6.985 & .000 \\
\hline
\end{tabular}

a. Dependent Variable: MinatPembelian

Ada pengaruh yang signifikan antara variabel $\mathrm{X}$ terhadap variabel $\mathrm{Y}$.

Tabel 5 Rangkuman Hasil Koefisien Jalur Substruktur 1

\begin{tabular}{cccccc}
\hline $\begin{array}{c}\text { Pengaruh Antar } \\
\text { Variabel }\end{array}$ & $\begin{array}{c}\text { Koefisien } \\
\text { Jalur (beta) }\end{array}$ & $\begin{array}{c}\text { Nilai } \\
\text { Sig }\end{array}$ & $\begin{array}{c}\text { Hasil } \\
\text { Pengujian }\end{array}$ & Koefisien Determinasi & $\begin{array}{c}\text { Koefisien Variabel } \\
\text { lain }\left(\boldsymbol{\rho}_{\mathbf{y}} \varepsilon_{\mathbf{1}}\right)\end{array}$ \\
\hline X terhadap Y & 0,577 & 0,000 & Ho ditolak & $0,332=33,2 \%$ & 0,8173 \\
\hline
\end{tabular}

Dari persamaan struktural substruktur 1 dapat diartikan bahwa: (1) minat Pembelian (Y) dipengaruhi oleh Kualitas Produk (X) secara simultan sebesar 33,2\% dan sisanya sebesar 66,8\% dipengaruhi oleh variabel-variabel lain diluar penelitian ini. (2) Setiap peningkatan nilai Kualitas Produk (X) sebesar satu, maka Minat Pembelian (Y) akan naik sebesar 0,577. Begitu juga sebaliknya, setiap penurunan nilai Kualitas Produk (X) sebesar satu maka Minat Pembelian (Y) juga akan turun sebesar 0,577. 


\section{Analisis Pengaruh Kualitas Produk dan Minat Pembelian terhadap Keputusan Pembelian}

Selanjutnya, untuk melihat hubungan $\mathrm{X}$ dan $\mathrm{Y}$ terhadap $\mathrm{Z}$ dibantu dengan menggunakan program SPSS yang menghasilkan output yang menggambarkan hubungan tersebut. Adapun hasil output tersebut adalah sebagai berikut:

Tabel 6 Descriptive Statistics X, Y dan Z

\begin{tabular}{llrr}
\multicolumn{4}{c}{ Descriptive Statistics } \\
\hline & Mean & Std. Deviation & N \\
\hline KeputusanPembelian & 3.447076 & .4970745 & 100 \\
KualitasProduk & 3.473963 & .5886817 & 100 \\
MinatPembelian & 3.396837 & .5495736 & 100 \\
\hline
\end{tabular}

Pada tabel 6, terlihat mean dari variabel Keputusan Pembelian $(Z)=3,447076$ yang apabila mengacu pada tabel 3, maka dapat dikatakan bahwa keputusan pembelian konsumen J\&C Cookies dinilai baik. Selain itu, dari tabel terlihat bahwa Standard Deviation untuk variabel Z cenderung kecil sehingga dapat diketahui bahwa variasi jawaban responden cenderung seragam

\section{Pengujian Secara Simultan antara Variabel Bebas X dan Y dengan Variabel Terikat Z}

Ada pengaruh secara simultan yang signifikan antara variabel $\mathrm{X}$ dan $\mathrm{Y}$ terhadap variabel $\mathrm{Z}$. Maka dari itu, pengujian secara individual dapat dilakukan atau dilanjutkan.

Tabel 7 Model Summary Substruktur 2

\begin{tabular}{lrrrr}
\multicolumn{4}{c}{ Model Summary $^{\mathbf{b}}$} \\
\hline Model & R & R Square & $\begin{array}{c}\text { Adjusted R } \\
\text { Square }\end{array}$ & $\begin{array}{c}\text { Std. Error of the } \\
\text { Estimate }\end{array}$ \\
\hline 1 & $.586^{\mathrm{a}}$ & .343 & .330 & .4070240 \\
\hline
\end{tabular}

a. Predictors: (Constant), MinatPembelian, KualitasProduk

b. Dependent Variable: KeputusanPembelian

Besarnya pengaruh variabel $\mathrm{X}$ dan $\mathrm{Y}$ secara simultan terhadap variabel $\mathrm{Z}$ dapat diketahui dengan melihat nilai Rsquare pada Tabel 7, dengan nilai $\mathrm{R}^{2}=0,343=34,3 \%$. Jadi, nilai dari variabel $\mathrm{Z}$ dipengaruhi oleh variabel $\mathrm{X}$ dan $\mathrm{Y}$ sebesar 34,3\%, sedangkan sisanya sebesar $65,7 \%$ dipengaruhi oleh variabel lain di luar penelitian ini. Sementara itu, besarnya koefisien jalur bagi variabel lain di luar penelitian yang memengaruhi nilai variabel $Z(\rho Z)=\sqrt{1-R^{2}}=\sqrt{1-0,343}=0,8106$. Masih mengacu pada Tabel 7, nilai $\mathrm{R}$ (koefisien korelasi) diketahui sebesar 0,586. Hal ini berarti hubungan antara variabel bebas X dan Y secara bersama-sama dengan variabel terikat Z bersifat kuat (karena nilai $\mathrm{R}$ lebih besar dari 0,5) dan searah (karena nilai $\mathrm{R}$ positif). 


\section{Pengujian Secara Individual antara Variabel $\mathbf{X}$ terhadap $Z$}

Tabel 8 Coefficients Substruktur 2

\begin{tabular}{|ll|r|r|r|r|r|}
\hline \multicolumn{2}{|c|}{ Model } & \multicolumn{2}{|c|}{$\begin{array}{c}\text { Unstandardized } \\
\text { Coefficients }\end{array}$} & $\begin{array}{c}\text { Standardized } \\
\text { Coefficients }\end{array}$ & \multirow{2}{*}{ t } & \multirow{2}{*}{ Sig. } \\
\cline { 2 - 5 } & \multicolumn{1}{|c|}{ B } & Std. Error & \multicolumn{1}{c|}{ Beta } & & \\
\hline 1 & (Constant) & 1.497 & .282 & & 5.318 & .000 \\
& KualitasProduk & .350 & .085 & .415 & 4.117 & .000 \\
& MinatPembelian & .216 & .091 & .239 & 2.370 & .020 \\
\hline
\end{tabular}

a. Dependent Variable: KeputusanPembelian

Ada pengaruh yang signifikan antara variabel $\mathrm{X}$ terhadap variabel $\mathrm{Z}$.

\section{Pengujian secara Individual antara Variabel Y terhadap Z}

Ada pengaruh yang signifikan antara variabel Y terhadap variabel Z.

Tabel 9 Rangkuman Hasil Koefisien Jalur Substruktur 2

\begin{tabular}{cccccc}
\hline $\begin{array}{c}\text { Pengaruh } \\
\text { Antar Variabel }\end{array}$ & $\begin{array}{c}\text { Koefisien } \\
\text { Jalur (beta) }\end{array}$ & $\begin{array}{c}\text { Nilai } \\
\text { Sig }\end{array}$ & $\begin{array}{c}\text { Hasil } \\
\text { Pengujian }\end{array}$ & $\begin{array}{c}\text { Koefisien } \\
\text { Determinasi }\end{array}$ & $\begin{array}{c}\text { Koefisien Variabel } \\
\text { lain }\left(\boldsymbol{\rho}_{\mathbf{z}} \boldsymbol{\varepsilon}_{\mathbf{2}}\right)\end{array}$ \\
\hline X terhadap Z & 0,415 & 0,000 & Ho ditolak & $0,343=34,3 \%$ & 0,8106 \\
Y terhadap Z & 0,239 & 0,020 & Ho ditolak & & 0,806 \\
\hline
\end{tabular}

Dari persamaan struktural substruktur 2 dapat diartikan bahwa: (1) keputusan Pembelian (Z) dipengaruhi oleh Kualitas Produk (X) dan Minat Pembelian (Y) secara simultan sebesar 34,3\% dan sisanya sebesar $65,7 \%$ dipengaruhi oleh variabel-variabel lain di luar penelitian ini. (2) Setiap peningkatan nilai Kualitas Produk (X) sebesar satu, maka Keputusan Pembelian (Z) akan naik sebesar 0,415. Begitu juga sebaliknya, setiap penurunan nilai Kualitas Produk (X) sebesar satu maka Keputusan Pembelian (Z) juga akan turun sebesar 0,415. (3) Setiap peningkatan nilai Minat Pembelian(Y) sebesar satu, maka Keputusan Pembelian (Z) juga akan naik sebesar 0,239. Begitu juga sebaliknya, setiap penurunan nilai Minat Pembelian (Y) sebesar satu maka Keputusan Pembelian (Z) juga akan turun sebesar 0,239 .

\section{Hubungan Kausal Empiris Variabel X dan Y terhadap Z Setelah Trimming}

Tabel 10 Rangkuman Hubungan Kausal Empiris Variabel X dan Y terhadap Z

\begin{tabular}{|c|c|c|c|c|c|}
\hline \multirow[b]{2}{*}{ Variabel } & \multirow{2}{*}{$\begin{array}{c}\text { Koefisien } \\
\text { Jalur }\end{array}$} & \multicolumn{3}{|c|}{ Pengaruh Kausal } & \multirow{2}{*}{$\begin{array}{l}\text { Pengaruh } \\
\text { Bersama }\end{array}$} \\
\hline & & Langsung & Tidak Langsung Melalui Y & Total & \\
\hline X terhadap Y & 0,577 & 0,577 & $0,557+(0,557 \times 0,239)=0,7149$ & 1,291 & - \\
\hline $\mathrm{X}$ terhadap Z & 0,415 & 0,415 & - & 0,415 & - \\
\hline Y terhadap Z & 0,239 & 0,239 & - & 0,239 & - \\
\hline$\varepsilon_{1}$ & 0,8173 & $0,8173^{2}=0,668$ & - & - & - \\
\hline$\varepsilon_{2}$ & 0,8106 & $0,8106^{2}=0,657$ & - & - & - \\
\hline X & - & - & - & - & 0,332 \\
\hline Xdan Y & - & - & - & - & 0,343 \\
\hline
\end{tabular}


Berdasarkan Tabel 10, dapat ditarik kesimpulan sehingga memberikan informasi sebagai berikut. Pertama, hipotesis pertama yang berbunyi "Ada pengaruh secara simultan yang signifikan antara variabel X terhadap variabel Y", bahwa secara keseluruhan menyatakan signifikan. Demikian pula, secara individual semua sub-variabel diterima, karena berdasarkan pengujian koefisien jalur substruktur 1, koefisien jalur variabel X secara statistik adalah signifikan. Dengan demikian, dapat diperoleh informasi bahwa kualitas produk $(\mathrm{X})$ berpengaruh secara simultan dan signifikan terhadap minat pembelian (Y). Besarnya pengaruh kualitas produk terhadap minat pembelian sebesar 0,577 Sedangkan besarnya pengaruh kualitas produk berpengaruh secara tidak langsung yang memengaruhi minat pembelian adalah 0,7149 .

Kedua, hipotesis kedua yang berbunyi berbunyi "Ada pengaruh secara simultan yang signifikan antara variabel X dan Y terhadap variabel Z", bahwa secara keseluruhan menyatakan signifikan. Demikian pula, secara individual semua subvariabel diterima, karena berdasarkan pengujian jalur substruktur 2, koefisien jalur variabel $\mathrm{X}$ dan $\mathrm{Y}$ secara statistik adalah signifikan. Dengan demikian, dapat diperoleh informasi bahwa kualitas produk (X) dan minat pembelian (Y) berpengaruh secara simultan dan signifikan terhadap keputusan pembelian (Z). Besarnya pengaruh kualitas produk terhadap keputusan pembelian sebesar 0,415 dan pengaruh minat pembelian terhadap keputusan pembelian sebesar 0,239.

Ketiga, dari tabel 10 dapat diketahui bahwa variabel Kualitas Produk (X) memberikan pengaruh sebesar 0,577 bagi Minat Pembelian (Y). Namun pengaruh yang diberikan Minat Pembelian (Y) kepada Keputusan Pembelian (Z) justru menurun menjadi 0,239. Hal ini dapat disebabkan oleh pengaruh dari variabel lain di luar penelitian ini yang diketahui sebesar 0,8173 . Sehingga, meskipun variabel Kualitas Produk (X) mendapat perhatian yang cukup baik dari perusahaan, variabel lain tidak diperhatikan dengan baik oleh perusahaan, maka variabel lain tersebut akan menurunkan pengaruh bersama kepada Minat Pembelian (Y), dan akibatnya pengaruh Minat Pembelian (Y) kepada Keputusan Pembelian (Z) menurun.

\section{SIMPULAN}

Berdasarkan hasil penelitian setelah menguji dan menganalisis, maka dapat ditarik kesimpulan sebagai berikut. Pertama, terdapat pengaruh secara positif dan signifikan antara kualitas produk terhadap minat beli J\&C Cookies. J\&C Cookies dapat terus menerapkan berbagai hal yang dapat meningkatkan kualitas produk karena terbukti dapat meningkatkatkan minat beli pelangganya. Kedua, terdapat pengaruh secara positif dan signifikan antara minat beli terhadap proses keputusan pembelian J\&C Cookies. J\&C Cookies dapat melakukan berbagai cara yang dapat meningkatkan minat beli karena akan membantu peningkatan proses keputusan pembelian pelanggan J\&C Cookies. Ketiga, terdapat pengaruh secara positif dan signifikan antara kualitas produk terhadap proses keputusan pembelian pelanggan J\&C Cookies. J\&C Cookies dapat menerapkan berbagai elemen di dalam kualitas produk yang mampu memberikan pengaruh yang positif terhadap proses keputusan pembelian pelanggan J\&C Cookies. Keempat, kualitas produk terbukti memberikan pengaruh yang besar terhadap minat beli pelanggan dan berdampak pada proses keputusan pembelian pelanggan J\&C Cookies yang positif dan besar. Ini ditunjukkan dengan meskipun variabel Kualitas Produk (X) mendapat perhatian yang cukup baik dari perusahaan, variabel lain tidak diperhatikan dengan baik oleh perusahaan, maka variabel lain tersebut akan menurunkan pengaruh bersama kepada Minat Pembelian (Y), dan akibatnya pengaruh Minat Pembelian (Y) kepada Keputusan Pembelian (Z) menurun.

Dengan memerhatikan hasil analisis dan pembahasan di atas, penulis mencoba mengajukan saran sebagai berikut. Pertama, meskipun telah menerapkan HACCP yaitu sistem yang memberikan jaminan yang berstandar internasional dalam menghasilkan makanan yang aman bagi konsumen, 
konsumen belum menyadari pentingnya sistem HACCP yang diterapkan oleh J\&C Cookies. Hal itu disebabkan tingkat kesadaran akan kesehatan yang masih kurang pada masyarakat Indonesia dan kurangnya informasi yang diberikan oleh J\&C Cookies. Untuk itu perusahaan disarankan agar memberikan informasi dan penyuluhan kepada masyarakat dan konsumen J\&C Cookies seperti memberikan brosur kepada konsumen pada setiap pembelian kue keringnya tentang dampak mengonsumsi makanan yang tidak aman dan keunggulan menggunakan sistem HACCP. Dengan demikian, masyarakat dan konsumen dapat lebih aware terhadap makanan yang mereka konsumsi dan memberikan dampak positif pada J\&C Cookies yang telah menerapkan sistem HACCP.

Kedua, diharapkan J\&C Cookies dapat menambah aneka ragam kue kering yang ditawarkan kepada masyarakat. Seiring berkembangnya persaingan pada bisnis kue kering ini, perusahan J\&C Cookies dituntut untuk menambah jumlah varian rasa kue keringnya dengan melakukan riset terhadap konsumen tentang rasa dan varian apa yang sedang digemari oleh konsumen. Sehingga perusahaan dapat memenuhi kebutuhan konsumen. Ketiga, perusahaan disarankan untuk meningkatkan strategi promosi seperti meminta data konsumen ketika membeli kue kering, lalu konsumen diberi informasi tentang produk kue kering yang ditawarkan dan promosi seperti diskon atau reward sehingga konsumen akan membeli J\&C Cookies. Diharapkan dengan dilakukan promosi konsumen akan merasa puas terhadap service dan produk yang ditawarkan, dan dapat mempromosikan kepada orang lain untuk membeli kue kering J\&C Cookies.

\section{DAFTAR PUSTAKA}

Albari. (2002). Mengenal Perilaku Konsumen Mengenai Penelitian Motivasi. Jurnal Siasat Bisnis,Vol. 1 No.7. Yogyakarta.

Bambang. (2008). Pengaruh Harga dan Kualitas Produk terhadap Keputusan Konsumen Membeli Kendaraan Bermotor. Jurnal Ilmiah Indonesia. Vol.1 (no.2): 40-46. Jakarta.

Basu Swastha dan Irawan. (2005). Manajemen Pemasaran Modern. Yogyakarta: Liberty.

Budiyono, Bernard N. M. , ( 2004 ), "Studi Mengenai Pengembangan Strategi Produk (Studi Kasus Minat Beli Produk Baru Telkom Flexi di Surabaya)", Jurnal Sains Pemasaran Indonesia, vol. III No. 2 September 2004.

Darmawan dan Ferrinadewi. (2004). Perilaku Konsumen: Analisis Model Keputusan. Yogyakarta: Universitas Atma Jaya.

Durianto, D., dan Liana, C. (2004). Analisis efektivitas iklan televisi softener soft \& fresh di jakarta dan sekitarnya dengan menggunakan consumen decision model. Jurnal Ekonomi Perusahaan.Vol.11 (no.1): 35-55.

Durianto. (2004). Strategi Menaklukkan Pasar. Jakarta: Gramedia Pustaka Utama.

Ferdinand, A. (2002). Pengembangan Minat Beli Merek Ekstensi. Semarang: Badan Penerbit Universitas Diponegoro.

Hurriyati, R. (2005). Bauran Pemasaran dan Loyalitas Konsumen. Bandung: Alfabeta.

Kotler dan Amstrong. (2003). Dasar-Dasar Pemasaran. Jilid-1, Edisi ke-9. Jakarta: Indeks. 
Kotler dan Amstrong. (2004). Dasar-Dasar Pemasaran. Jilid-2, Edisi ke-9. Jakarta: Indeks.

Kotler, P. (2004). Manajemen Pemasaran. Jakarta: Erlangga.

Kotler, P. (2007). Manajemen Pemasaran. Jakarta: Indeks.

Ma’ruf, H. (2006). Pemasaran Ritel. Jakarta: Gramedia Pustaka Utama.

Riduwan dan Kuncoro, E. A. (2008). Cara Menggunakan dan Memakai Analisis Jalur (Path Analysis). Bandung: Alfabeta.

Sarjono, H., dan Julianita, W. (2011). SPSS vs LISREL: Sebuah Pengantar, Aplikasi untuk Riset. Jakarta: Salemba Empat.

Schiffman, L. G., dan Kanuk, L. L. (2007). Perilaku Konsumen. Jakarta: Indeks.

Schiffman, L.G., dan Kanuk, L. (2004). Consumer Behavior. Prentice Hall Internasional.

Sekaran, U. (2006). Metodologi Penelitian untuk Bisnis. Jilid Satu. Edisi 4. Jakarta: Salemba Empat.

Sugiyono. (2007). Metode Penelitian Bisnis. Bandung: Alfabeta.

Umar, H. (2005). Riset Pemasaran dan Perilaku Konsumen. Jakarta: Gramedia Pustaka Utama.

Utami, C. W. (2006). Manajemen Ritel: Strategi dan Implementasi Ritel Modern. Jakarta: Salemba Empat.

Yoestini, dan Eva Sheila. R. (2007). Jurnal Sains Pemasaran Indonesia. Vol VI.(no.3): 261-276, Jakarta. 